УДК 339.13

\title{
ІННОВАЦІЙНІ ПІДХОДИ ДО РОЗРОБКИ ТА ВИВЕДЕННЯ НА РИНОК БОРОШНЯНИХ ВИРОБІВ ФУНКЦІОНАЛЬНОГО ПРИЗНАЧЕННЯ
}

\section{INNOVATIVE APPROACHES TO THE DEVELOPMENT AND MARKETING OF FUNCTIONAL PRODUCTS OF FLOUR PRODUCTS}

\author{
Чуйко Марина Миколаївна \\ кандидат технічних наук, \\ Харківський торговельно-економічний інститут \\ Київського національного торговельно-економічного університету \\ ORCID: https://orcid.org/0000-0001-9380-8735 \\ Чуйко Андрій Миколайович \\ кандидат технічних наук, старший науковий співробітник, \\ Харківський національний університет імені В.Н. Каразіна \\ ORCID: https://orcid.org/0000-0003-2551-844X \\ Chuiko Maryna \\ Kharkiv Institute of Trade and Economics \\ of Kyiv National University of Trade and Economics \\ Chuiko Andrii \\ V.N. Karazin Kharkiv National University
}

\begin{abstract}
Стаття присвячена актуальним питанням розроблення теоретичної моделі створення борошняних виробів функціонального призначення високої якості. Проаналізовано та систематизовано інформаційну підготовку до моделювання необмеженого асортименту борошняної продукції направленої дії. Окреслено вимоги до визначення дефіцитних нутрієнтів, визначення груп борошняних виробів для збагачення, моделювання рецептур і технологій із використанням сучасних методів розрахунків збалансованості основних нутрієнтів, а також можливості виведення на промисловий рівень та споживчий ринок борошняних виробів функціонального призначення високої якості. Використання запропонованої моделі дозволяє фрормувати борошняні вироби функціонального призначення високої якості з урахуванням вимог і потреб споживачів, що повною мірою відповідає маркетинговим законам і вимогам системи менеджменту якості.

Ключові слова: інновації, функціональні продукти, борошняні вироби, дефіцитні нутрієнти, споживчі властивості, конкурентоспроможність, споживчий ринок, економічна ефективність, соціальна значимість.

Статья посвящена актуальным вопросам разработки теоретической модели создания мучных изделий фрункционального назначения высокого качества. Проанализировано и систематизировано информационную подготовку к моделированию неограниченного ассортимента мучной продукции направленного действия. Определены требования к использованию десицитных нутриентов, групп мучных изделий для обогащения, моделированию рецептур и технологий с использованием современных методов расчетов сбалансированности основных нутриентов, а также возможности вывода на промышленный уровень и потребительский рынок мучных изделий фрунциинального назначения высокого качества. Использование предложенной модели позволяет фрормировать мучные изделия фрункционального назначения высокого качества с учетом требований и потребностей потребителей, что в полной мере соответствует маркетинговым законам и требованиям системы менеджмента качества.

Ключевые слова: инновации, функциональные продукты, мучные изделия, дефицитные нутриенты, потребительские свойства, конкурентоспособность, потребительский рынок, экономическая эффрективность, социальная значимость.
\end{abstract}

The aim of the work is to develop theoretical approaches and practical aspects of creating high-quality functional flour products. The relevance of the topic is that the most effective and expedient from an economic, social, hygien- 
ic and technological point of view way to radically solve the problem of enrichment of flour products with missing food components is the development and industrial production of various specialized flour products, additionally enriched with missing vitamins, macronutrients and trace elements, dietary fiber and other components to a level that meets the physiological needs of man. Unresolved today is the development of theoretical approaches and practical aspects of introduction into production in the necessary quantities available for different social and age groups of high-quality functional flour products, which will reduce the incidence of diseases caused by insufficient nutrient intake, overcome the consequences of vitamin and mineral deficiencies. substances, as well as ensure the normal growth and development of children, will prolong people's lives, increase efficiency and create conditions for their adaptation to the environment. The article is devoted to topical issues of developing a theoretical model of creating high-quality functional flour products. The information preparation for modeling of the unlimited assortment of flour products of the directed action is analyzed and systematized. The requirements for determining deficient nutrients, determining groups of flour products for enrichment, determining compliance with medical-biological, physico-chemical, functional-technological and consumer requirements, modeling of recipes and technologies using modern methods of calculating the balance of basic nutrients, as well as the possibility of introduction to industrial the level of high-quality functional flour products. The use of the proposed model allows to form high-quality functional flour products taking into account the requirements and needs of consumers, which fully meets the marketing laws and requirements of the quality management system, which is the basis of competitiveness in any production. Increasing the production of competitive functional flour products, in turn, is very appropriate for the country from a socio-economic point of view.

Keywords: innovations, functional products, flour products, deficient nutrients, consumer properties, competitiveness, consumer market, economic efficiency, social significance.

Постановка проблеми. Як відомо, харчування завжди було і є одним із найважливіших чинників, які забезпечують зв'язок людського організму з навколишнім середовищем і надає вирішального впливу на стан здоров'я, працездатність, розумову діяльність, витривалість організму до впливу шкідливих фракторів виробничого, техногенного та природного походження. Особливе значення для підтримки стану здоров'я та довголіття людини має повноцінне та регулярне забезпечення її організму усіма необхідними компонентами: харчовими волокнами, ненасиченими жирними кислотами, незамінними амінокислотами, вітамінами, мінеральними складовими тощо. Причому найбільш доцільним і фрізіологічним шляхом надходження цих складових до організму $є$ харчовий.

Найбільший сегмент серед продуктів харчування завжди займали борошняні вироби. Асортимент борошняних виробів дуже різноманітний. Це, насамперед, хлібобулочні, макаронні вироби, борошняні кондитерські, кулінарні й інші вироби, споживання яких в усьому світі в загальному обсязі продуктів харчування займає досить вагоме місце. Тому виробництво борошняних виробів, що характеризуються підвищеною харчовою і біологічною цінністю з високими споживчими властивостями, $є$ актуальною проблемою для України, яка опинилася в умовах економічної й екологічної криз. Ситуація, що створилася, привела до того, що поряд зі зниженням харчової цінності борошняних виробів зменшилося споживання основних харчових речовин, мікронутрієнтів, вітамінів і т. ін. Наслідком такого дисбалансу в харчуванні з'явилося збільшення росту цілого ряду захворювань: серцево-судинних, шлункових, онкологічних, мікроелементозів і інших, що приймає для України загрозливі розміри.

Зараз в світі продовжується стратегія щодо створення так званої "здорової" їжі, основним напрямком якої $€$ зниження споживання насичених жирів, цукру, солі при одночасному підвищенні споживання харчових волокон, мінеральних речовин, вітамінів, антиоксидантів і т. ін. Тому особливого значення набуває розробка рецептур борошняних виробів лікувально-профрілактичного призначення, максимально збалансованих за основними харчовими речовинами, а також збагачених різноманітними добавками тваринного та рослинного походження, що додають борошняним виробам адаптогенні, біостимулюючі, антиоксидантні й інші фрункції. Важливо також, щоб збагачені борошняні вироби по можливості не відрізнялися від традиційних і мали високі показники якості.

Аналіз останніх досліджень і публікацій. 3 метою розробки теоретичних і формування практичних рекомендацій щодо збагачення борошняної продукції необхідними харчовими речовинами слід спочатку встановити, які харчові речовини, в якій формі і в яких кількостях слід вносити в ці продукти. Аналіз вітчизняної і зарубіжної літератури дозволяє сформулювати такі основні принципи збагачення борошняних продуктів масового споживання. По-перше, необхідно забезпечити умову без- 
печності, відповідно до якої сумарна кількість окремих речовин в добовому раціоні не повинна перевищувати безпечні рівні їх споживання. По-друге, фоорма, в якій вноситься той або інший компонент, повинна бути добре засвоюваною [1].

В цілому збагачення борошняних виробів різними харчовими компонентами має тривалу історію. Проте концепція фрункціонального харчування в Європі почала розвиватися лише з середини 90-х років минулого століття. Так, збагачення борошняних виробів у Франції, Нідерландах, Норвегії, Фінляндії, США і інших розвинених країнах світу дотепер залишається найбільш широко використовуваним механізмом корекції раціону харчування населення [2].

У світовому масштабі йде постійна робота зі створення нових видів функціональних продуктів, що володіють як широким спектром застосування, так і точковою спрямованістю на конкретний орган, систему, захворювання. Так, у Японії, Великобританії, Німеччині, Франції й інших розвинених країнах реалізуються відповідні цільові національні програми з оздоровлення населення шляхом біокорекції продуктів масового споживання. В Японії, наприклад, ринок фуункціональних продуктів оцінюється в 10-12 млрд. доларів на рік, а їх виробництво набуло стратегічної спрямованості [3].

Світовий досвід показує, що у всьому світі ринок фрункціональних харчових продуктів щорічно збільшується на 10-15 \%. Тому замість традиційних лікарських препаратів для зміцнення і відновлення здоров'я використовують біологічно активні добавки до їжі і функціональні харчові продукти [4]. Отже, найбільш ефективним і доцільним з економічної, соціальної, гігієнічної і технологічної точок зору способом кардинального вирішення проблеми збагачення борошняної продукції відсутніми харчовими компонентами $€$ розробка і створення промислового виробництва різноманітних спеціалізованих борошняних виробів, додатково збагачених відсутніми вітамінами, макро- і мікроелементами, харчовими волокнами і іншими компонентами до рівня, який відповідає фрізіологічним потребам людини.

Виділення невирішених раніше частин загальної проблеми. Сьогодні ще продовжується тенденція щодо розробки та виробництва нових вітамінно-мінеральних таблеток та преміксів, які пропонується вводити в раціон харчування окремо або в якості домішок до різних харчових продуктів. Проте кардинальним рішенням проблеми може стати лише широкомасштабне збагачення продуктів хар- чування, що споживаються всіма верствами населення. Саме такими продуктами є хліб, макаронні вироби, борошняні кондитерські вироби, борошняна кулінарна продукція тощо.

Отже, невирішеним залишається питання розробки теоретичних підходів та практичних аспектів впровадження у виробництво в необхідних кількостях доступної для різних соціальних та вікових груп населення борошняної продукції фрункціонального призначення високої якості, що дозволить знизити частоту захворювань, обумовлених недостатнім вживанням харчових речовин, подолати наслідки десріциту вітамінів, мінеральних речовин, а також забезпечить нормальне зростання i розвиток дітей, сприятиме подовженню життя людей, підвищенню працездатності і створить умови для адаптації їх до навколишнього середовища.

Формулювання цілей статті. Метою роботи $€$ розробка теоретичних підходів та практичних аспектів створення борошняних виробів фрункціонального призначення високої якості.

Виклад основного матеріалу дослідження. Функціональний борошняний продукт 3 раціональним вмістом нутрієнтів повинен мати потрібну організму людини харчову, енергетичну цінність та високі споживні та споживчі властивості. Вимоги до створення борошняних виробів фрункціонального призначення високої якості наведені на рис. 1.

Функціональна дія таких продуктів харчування полягає у наступному:

- підвищенні неспецисрічної резистентності організму до впливу несприятливих фракторів навколишнього середовища;

- профрілактиці низки хронічних захворювань (ожиріння, атеросклероз, серцевосудинні, онкологічні тощо);

- лікуванні захворювань, викликаних десріцитом або надлишком нутрієнтів;

- імуномодулюючій дії;

- зв'язуванні і виведенні ксенобіотиків.

На рис. 2 наведено розроблену нами теоретичну модель створення борошняних виробів фрункціонального призначення високої якості, яка складається зі взаємопов'язаних підсистем, реалізація яких повинна забезпечити необхідну якість продукції.

Розглянемо запропоновану модель більш детально. На першому етапі необхідно було зробити моніторинг харчування населення України борошняними виробами. Проведення моніторингу надало можливість отримання даних щодо харчового статусу населення, 


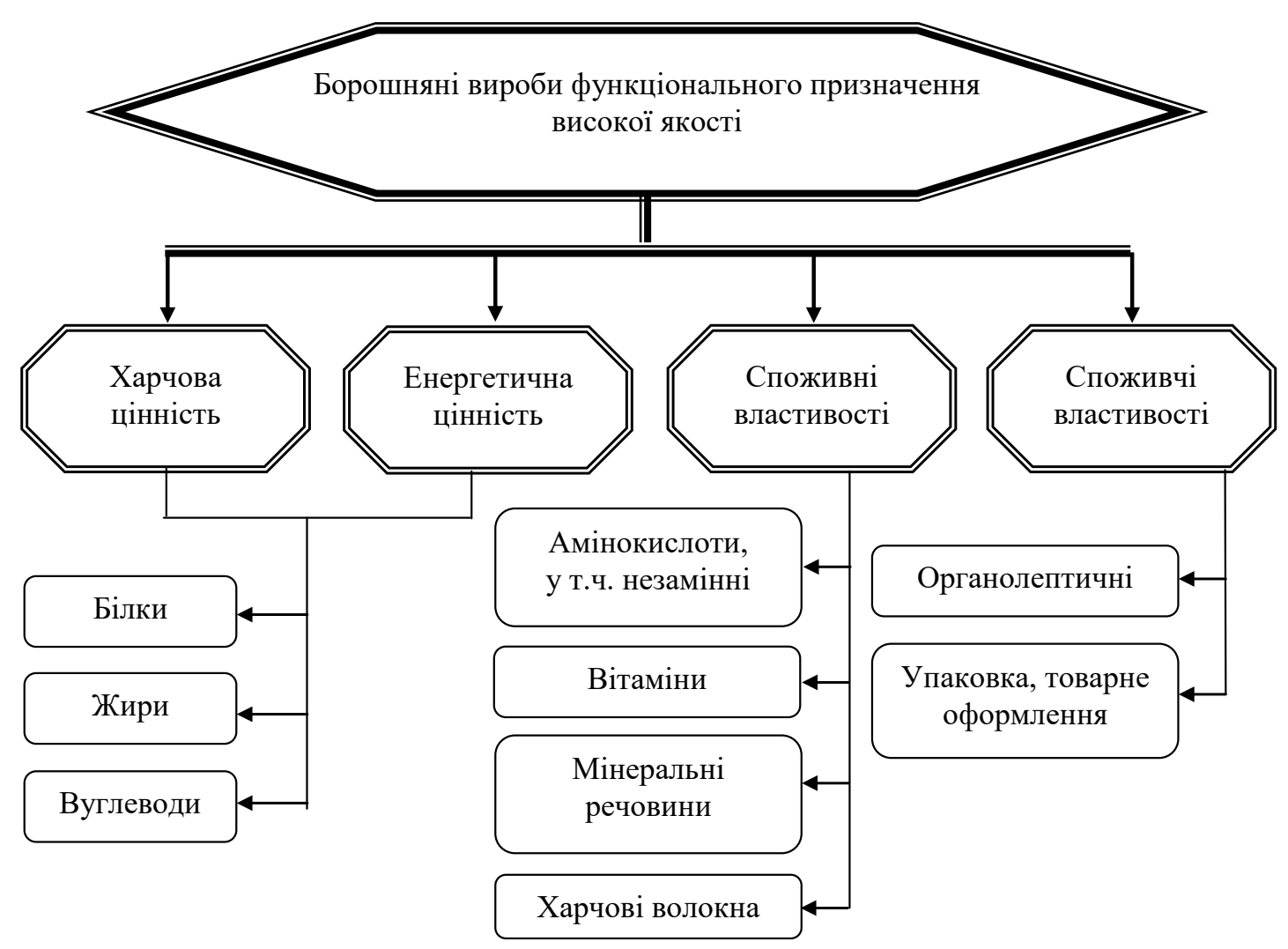

Рис. 1. Вимоги до створення борошняних виробів функціонального призначення високої якості

визначення його соціального і демографрічного стану, визначення фрактичного споживання борошняної продукції, стану здоров'я і норм орізіологічних потреб людини у основних харчових речовинах, тривалості життя та виявлення фракторів, що впливають на зазначені показники.

Пошук джерел збагачення борошняних виробів необхідними мікронутрієнтами природного походження здійснюється на основі теоретичних досліджень властивос-тей необхідних людині нутрієнтів, які доцільно вводити у борошняні вироби (рис. 3).

Джерела мікронутрієнтів для збагачення борошняних виробів повинні відповідати наступним вимогам:

- доступна вартість;

- економічна доцільність використання (з урахуванням вилучення із сировини);

- безпечність для здоров'я;

- наявність товарної кількості вихідної сировини;

- збереженість мікронутрієнтів в умовах різних технологічних режимів.

Для фрормування умов оптимального засвоєння борошняного продукту фрункціонального призначення та його високих органолептичних показників важливе зна- чення має правильний вибір продукту, який підлягає збагаченню. Тому необхідно враховувати сумісність компонентів борошняного виробу і харчової добавки за хімічним складом, смаковими якостями, фрізико-хімічними показниками, які впливають на фрункціонально-технологічні властивості готового продукту.

Слід відмітити, що хліб іхлібобулочні вироби 3 невеликою кількістю жиру доцільно збагачувати $\mathrm{Ca}, \mathrm{Fe}$, вітамінами групи В. Борошняні кулінарні вироби (пиріжки, пончики, чебуреки, біляші), здобні хлібні вироби, борошняні страви (млинці, млинчики, оладки) та борошняні кондитерські вироби (кекси, рулети, печиво, тістечка, торти), що містять значну кількість жиру, доцільно збагачувати жиророзчинними вітамінами A, D, E, каротином.

На сьогоднішній день для товаровиробника найбільш пріоритетними $є$ вимоги споживачів, які, зазвичай, вибирають продукти не за користю для здоров'я, а за смаком і зовнішнім виглядом. Тому при виборі борошняних виробів для збагачення їх нутрієнтами поряд 3 фрормуванням лікувально-профрілактичних властивостей слід обов'язково враховувати високі органолептичні показники продукції у відповідності до вимог споживачів, а також 


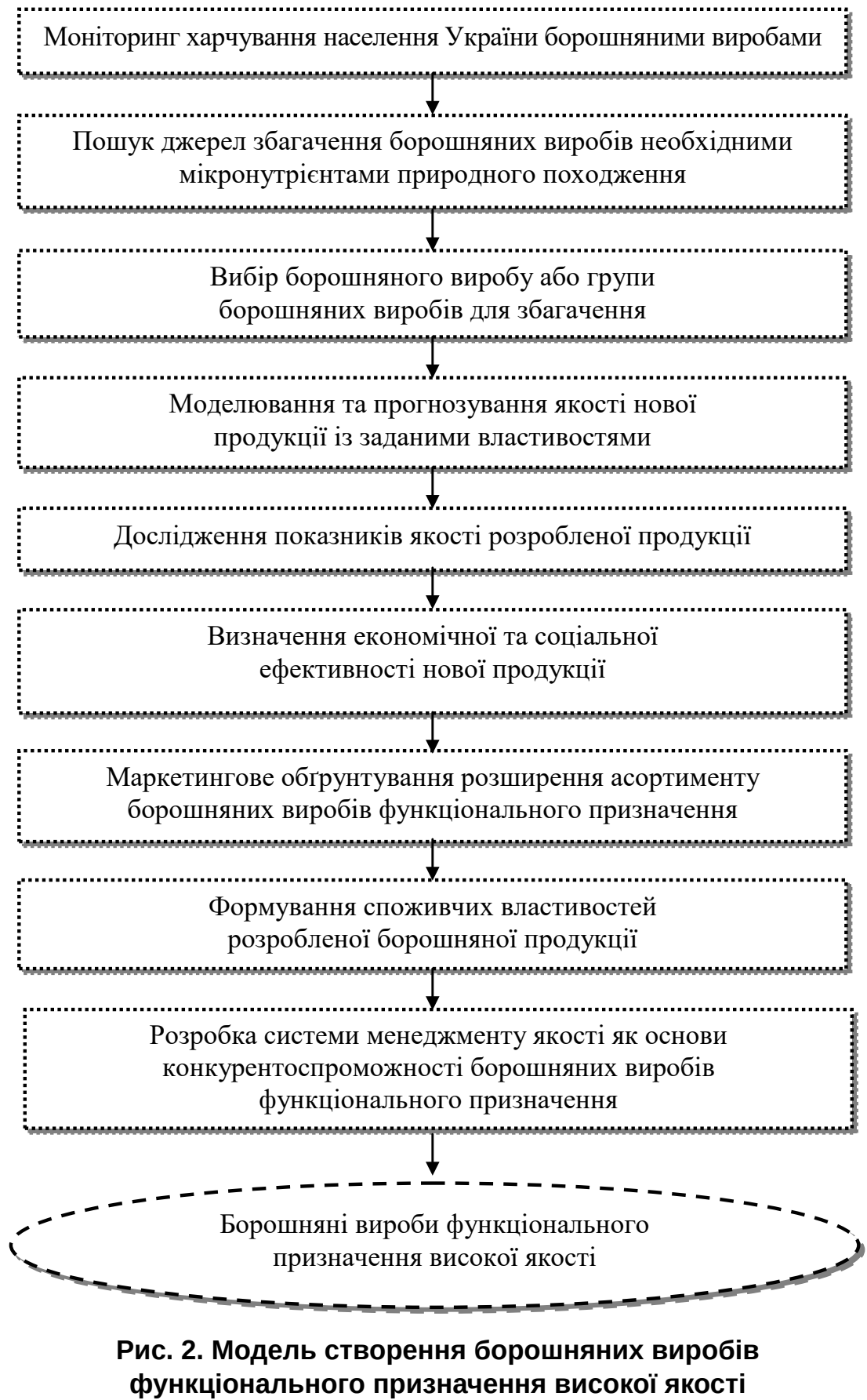

використовувати борошняні вироби масового споживання, доступні для різних соціальних і вікових груп населення. Також товаровиробником доцільно проводити збагачення борошняних виробів для певних груп населення, які можна класифрікувати за потребами у визначених нутрієнтах (дитяче харчування, харчування вагітних жінок, військовослужбовців, санаторно-курортних установ тощо). Модель вибору борошняних виробів для збагачення наведена на рис. 4.

Вміст важливих нутрієнтів у збагачених ними борошняних виробах повинен бути достатнім для задоволення не менше 15-30 \% середньої добової потреби в цих нутрієнтах при звичайному рівні споживання виробів. Такі норми прийняті на сьогодні у більшості країн світу, адже десріцит нутрієнтів у звичайному раціоні сучасної людини знаходиться саме в таких межах (30-50 \% від їх рекомендованого рівня споживання). Таким чином, відповідно до цього принципу будьякий збагачений борошняний виріб дозволяє ефективно поповнити наявний десріцит в необхідних нутрієнтах і в той же час захищає від надмірного надлишку цих нутрієнтів 


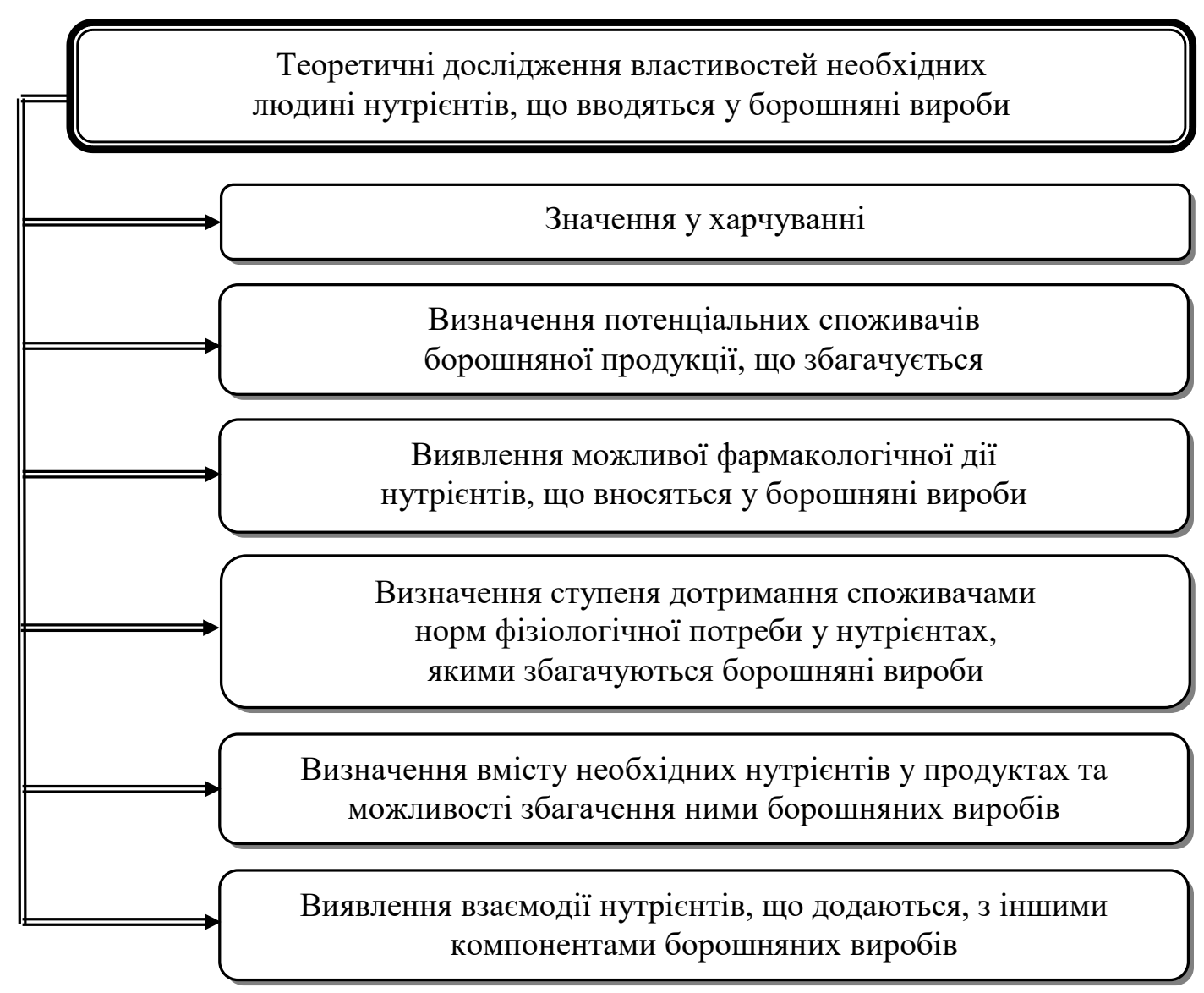

Рис. 3. Теоретичні аспекти визначення властивостей нутрієнтів, що плануються до введення в борошняні вироби для їх збагачення

навіть при одночасному включенні в раціон декількох збагачених продуктів. Дуже важливим залишається лише враховувати вміст внесених нутрієнтів у борошняному виробі, що збагачується, та можливість взаємодії внесених нутрієнтів з компонентами виробу, які можуть виявити негативний вплив. У той же час збагачений борошняний виріб повинен мати біологічну, енергетичну цінність, споживні властивості та містити за можливості у своєму складі нутрієнти, які відповідають потребам повноцінного харчування.

Під час моделювання борошняних виробів фрункціонального призначення слід вибирати такі способи внесення нутрієнтів, які б сприяли максимальному збереженню їх кількості, якості та забезпечували рівномірний розподіл по всій масі продукту. Досить важливим також $€$ те, щоб технологія внесення цінних нутрієнтів суттєво не ускладнювала технологічний процес виробництва продукту.

Формування орізико-хімічних та фрункціонально-технологічних властивостей борошняних виробів фрункціонального призначення наведено на рис. 5.
Найважливішим під час створення борошняних виробів фрункціонального призначення 3 товарознавчої точки зору $є$ фрормування споживчих властивостей. Формування споживчих властивостей борошняних виробів функціонального призначення наведено на рис. 6.

Видно, що фрормування органолептичних та споживних властивостей поряд 3 якісним упакуванням та обгрунтованою вартістю розробленої продукції $€$ важливим ланцюгом створення та споживання борошняних виробів функціонального призначення високої якості.

Важливо підкреслити, що упакування функціонального продукту повинно мати захисну дію, нести інорормацію про склад виробу, харчову цінність, лікувально-профрілактичні властивості та здійснювати маркетингову функцію. Також у разі наявності обмежень щодо норм споживання фрункціональних виробів на упакуванні це повинно бути відображено. Теоретичну модель виведення на промисловий рівень функціональних борошняних виробів наведено на рис. 7. 


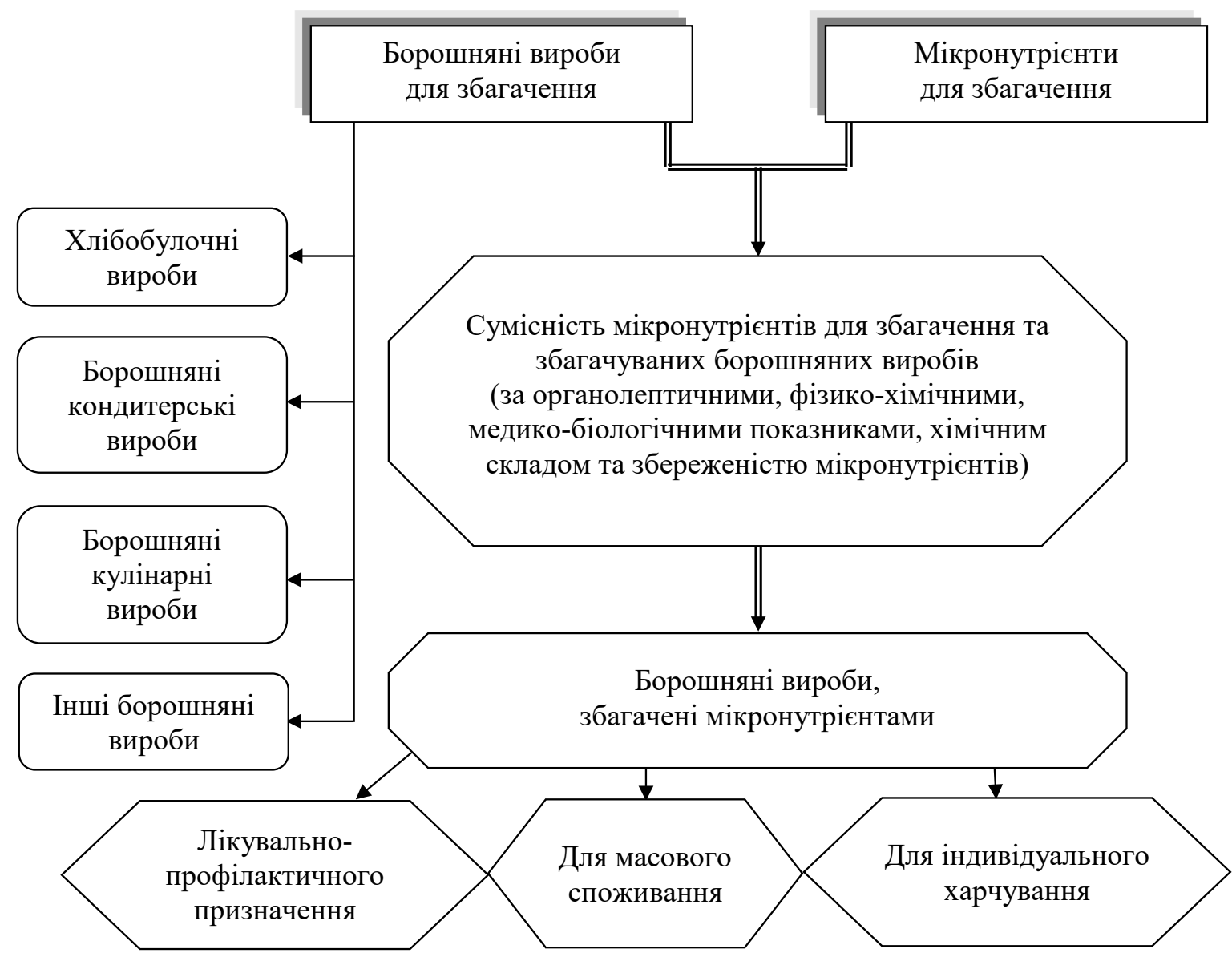

Рис. 4. Модель вибору борошняних виробів для збагачення

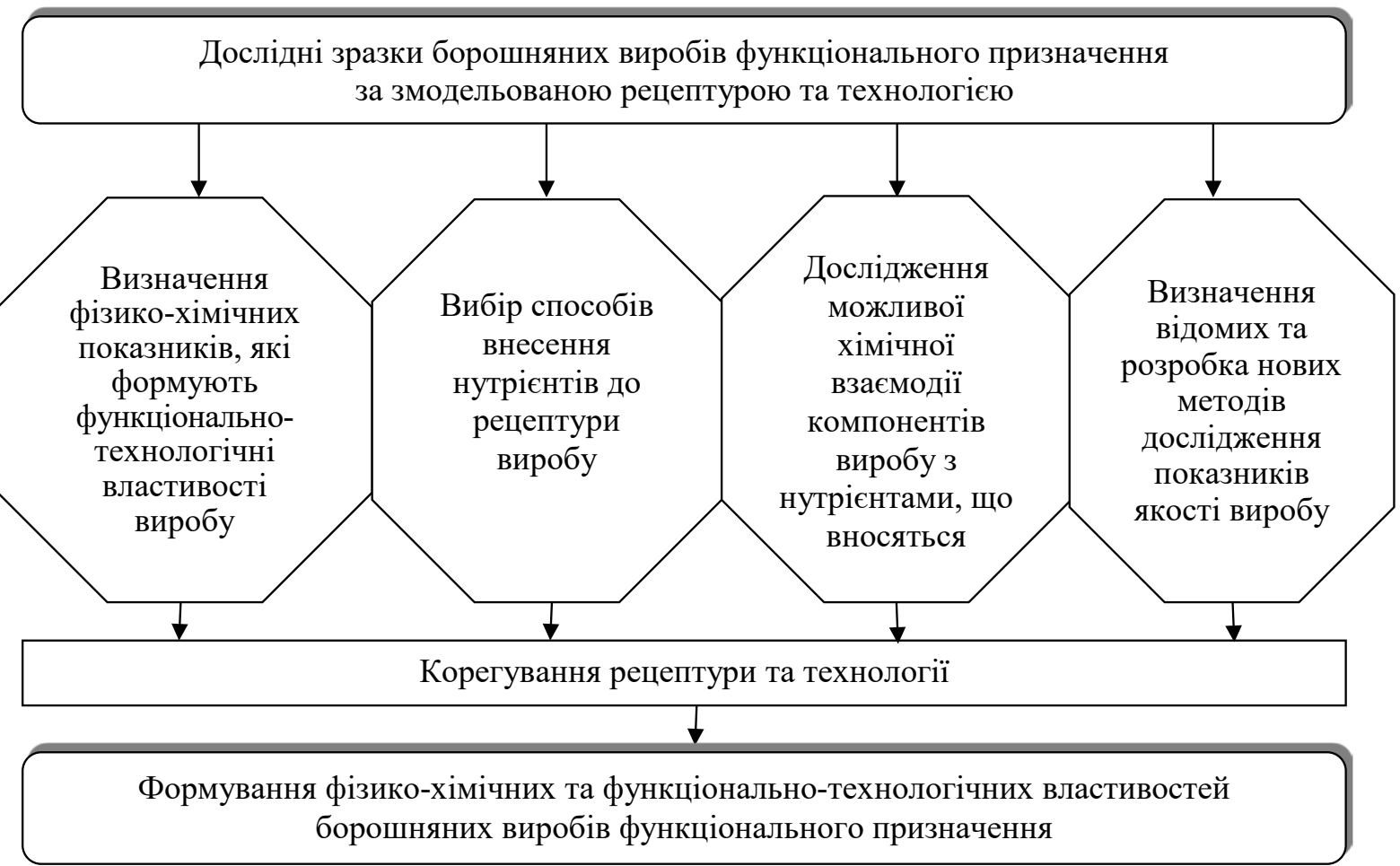

Рис. 5. Формування фізико-хімічних та функціонально-технологічних властивостей борошняних виробів функціонального призначення 


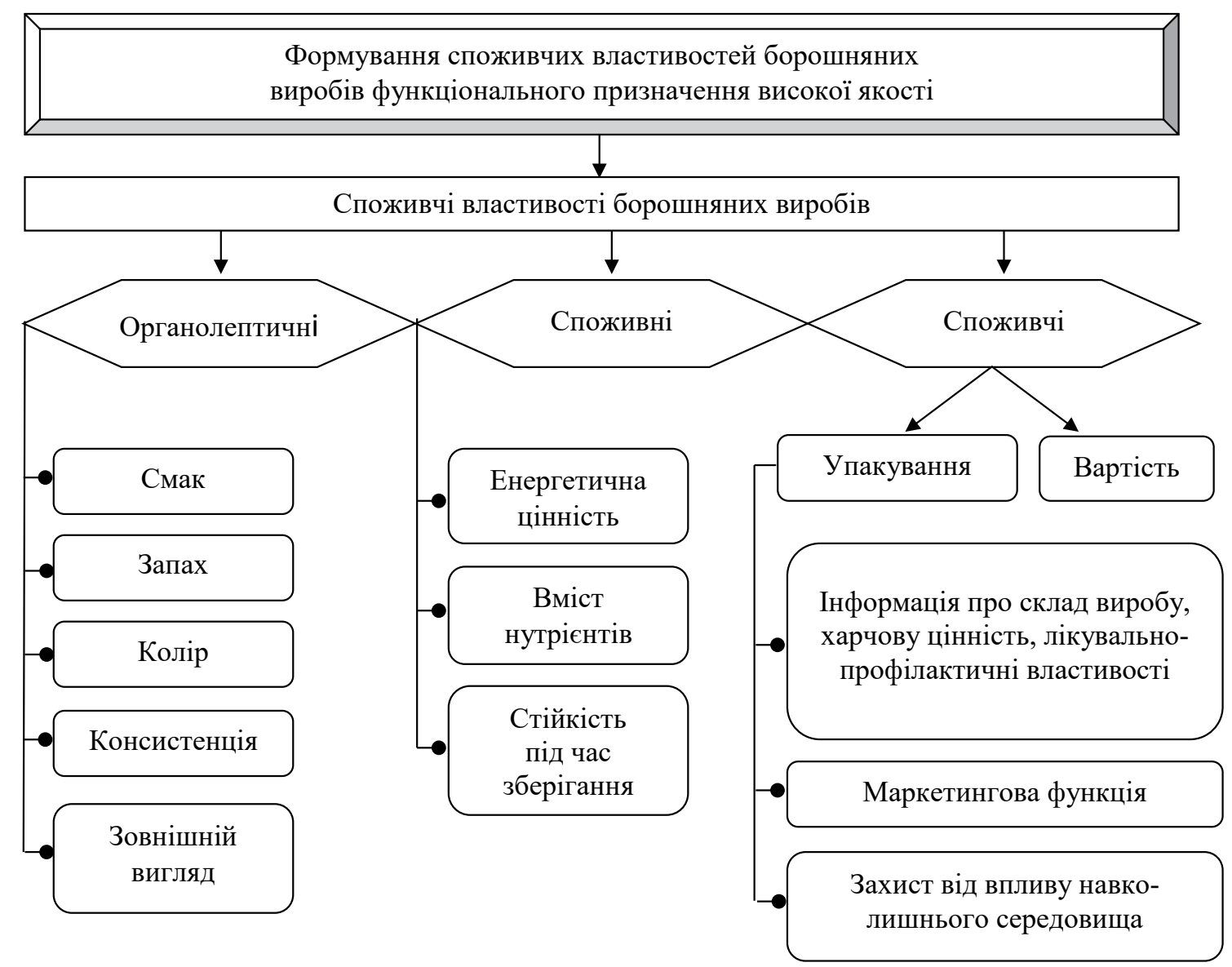

Рис. 6. Формування споживчих властивостей борошняних виробів функціонального призначення високої якості

Система HACCP (Hazard Analysis and Critical Control Point) прийнята в усьому світі і має на меті управління безпекою харчових продуктів на основі концепції аналізу ризиків і критичних точок контролю, а також дозволяє виділити усі потенційні ризики в харчовому продукті та запобігти їх виникненню. Тому розробка системи менеджменту якості як основи конкурентоспроможності борошняних виробів функціонального призначення, що представлена на завершальному етапі розробленої нами моделі (рис. 2), є вельми доцільною та актуальною.

Збільшення виробництва конкурентоспроможних борошняних виробів функціонального призначення $€$ дуже доцільним для країни із соціально-економічної точки зору. Визначення економічної і соціальної ефрективності виробництва борошняних виробів функціонального призначення наведено на рис. 8.

Економічна та соціальна ефрективність виробництва нової продукції має за мету забезпечення додаткових робочих місць, доступної вартості борошняних виробів фрункціонального призначення для всіх верств населення, надання користі для здоров'я та забезпечення конкурентоспроможності на ринку борошняної продукції.

Висновки. Розроблена теоретична модель створення борошняних виробів функціонального призначення забезпечує інформаційну підготовку до моделювання необмеженого асортименту борошняної продукції направленої дії. Вона включає вимоги до визначення дефріцитних нутрієнтів, визначення груп виробів для збагачення, визначення відповідності медико-біологічним, фрізико-хімічним, фрункціонально-технологічним та споживчим вимогам, моделювання рецептур і технологій, теоретичне визначення збалансованості основних нутрієнтів з використанням сучасних методів розрахунків та комп'ютерних технологій. Використання запропонованих моделей дозволяє формувати борошняні вироби функціонального призначення високої якості з урахуванням вимог і потреб споживачів, що повною мірою відповідає маркетинговим законам і вимогам системи менеджменту якості, яка $€$ основою конкурентоспроможності на будь-якому виробництві. 


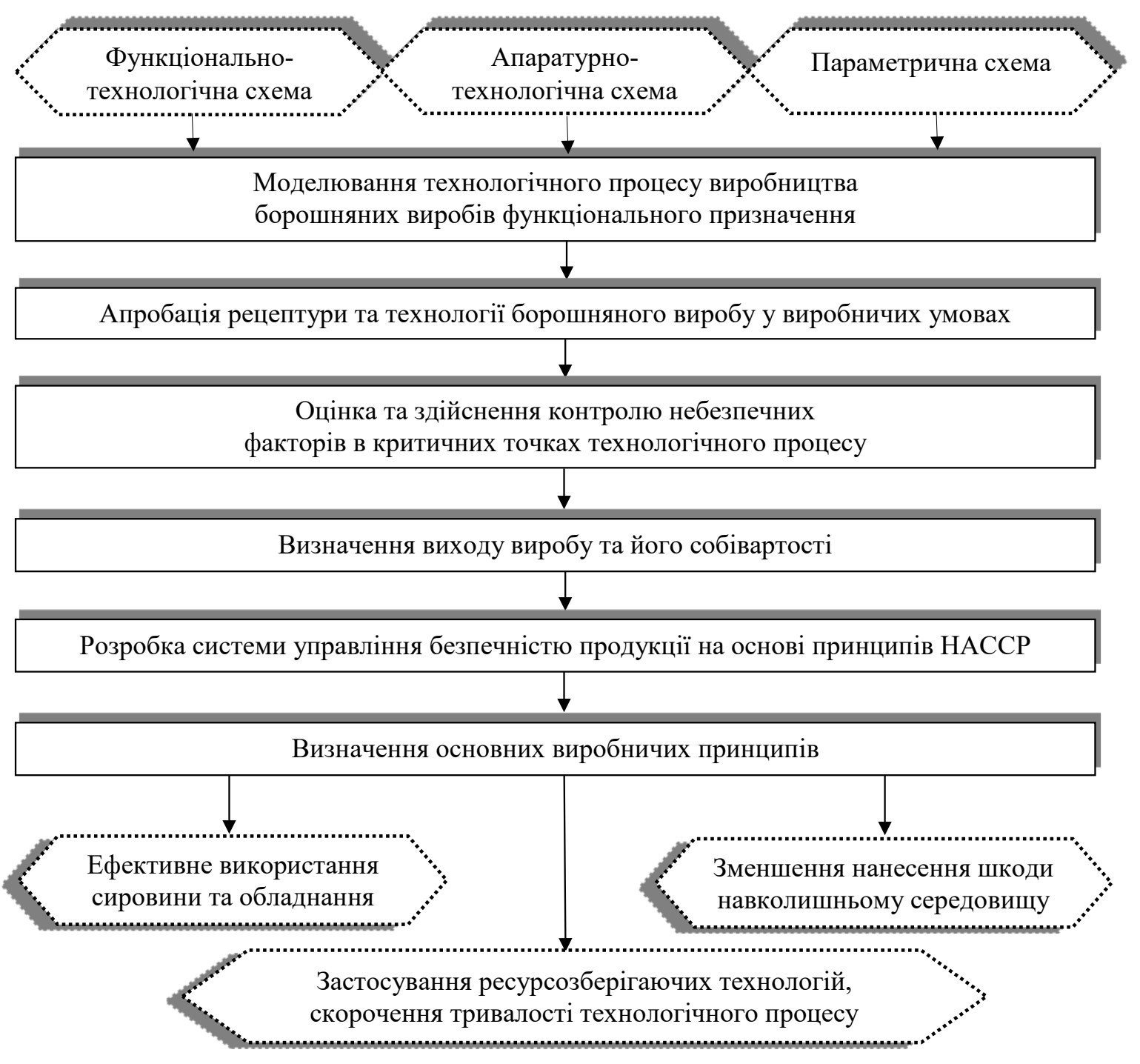

Рис. 7. Теоретична модель виведення на промисловий рівень виробів функціонального призначення

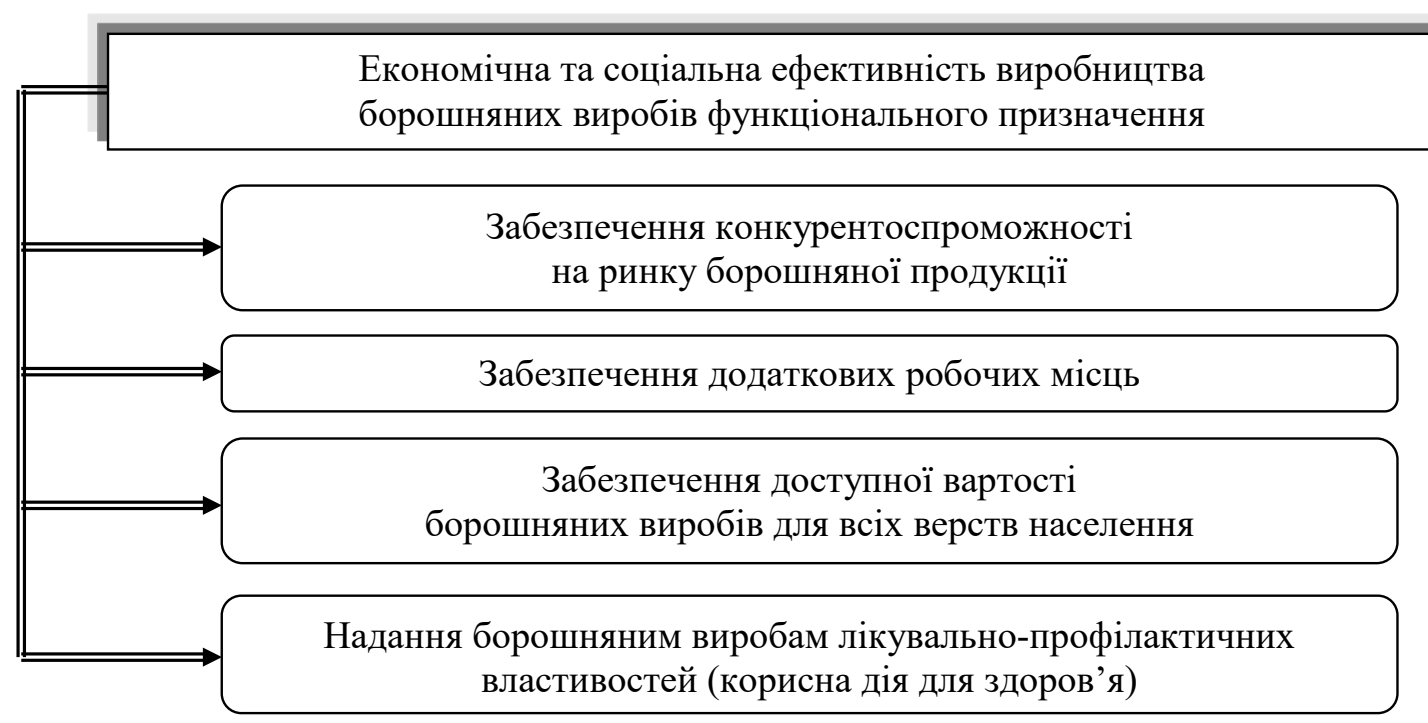

Рис. 8. Визначення економічної і соціальної ефективності виробництва борошняних виробів функціонального призначення 


\section{СПИСОК ВИКОРИСТАНИХ ДЖЕРЕЛ:}

1. Безпека харчових продуктів: антиаліментарні фрактори, ксксенобіотики, харчові добавки : навчальний посібник. Л.В. Кричковська, А.П. Бєлінська, В.В. Анан'єва. Харків : НТУ «ХП|», 2017. 98 с.

2. Жеоржеску Ч., Быркэ А.Г., Мячикова Н.И. Функциональные продукты питания в Европе. Научный результат. Серия «Технологии бизнеса и сервиса». 2016. № 3(9). URL: https://cyberleninka.ru/article/n/ funktsionalnye-produkty-pitaniya-v-evrope/viewer (дата звернення: 01.02.2021).

3. Никберг И.И. Функциональные продукты в структуре современного питания. Международный эндокринологический журнал. 2011. № 6(38). URL: http://www.mif-ua.com/archive/article/22542 (дата звернення: 01.02.2021).

4. Корзун В.Н., Тихоненко Ю.С. Функціональні продукти і їх роль у харчуванні людини. Наукові праці Одеської національної академії харчових технологій. 2010. № 38(2). С. 173-178.

\section{REFERENCES:}

1. Krychkovska L.V., Bjelinska A.P., Ananjeva V.V. (2017) Bezpeka harchovyh produktiv: antyalimentarni faktory, ksksenobiotyky, harchovi dobavky [Food safety: antialimentary factors, xenobiotics, food additives]: navchal'nyj posibnyk [a textbook]. Kharkiv: NTU «HPI», 98 p. (in Ukrainian)

2. Zheorzhesku Ch., Byrkje A.G., Mjachikova N.I. (2016) Funkcional'nye produkty pitanija v Evrope [Functional food products in Europe]. Nauchnyj rezul'tat. Serija «Tehnologii biznesa i servisa». no. 3(9). Available at: https://cyberleninka.ru/article/n/funktsionalnye-produkty-pitaniya-v-evrope/viewer (accessed 1 February 2021).

3. Nikberg I.I. (2011) Funkcionalnye produkty v strukture sovremennogo pitanija [Functional products in the structure of modern nutrition]. Mezhdunarodnyj jendokrinologicheskij zhurnal, no. 6(38). Available at: http://www.mif-ua.com/archive/article/22542 (accessed 1 February 2021).

4. Korzun V.N., Tyhonenko Ju.S. (2010) Funkcional'ni produkty $\mathrm{i}$ in rol u harchuvanni ljudyny [Functional products and their role in the hungry people]. Naukovi praci Odeskoi nacionalnoi akademii harchovyh tehnologij, no. 38(2), pp. 173-178. 